\title{
US Public Institution
}

National Cancer Institute

\section{Source}

National Cancer Institute. US Public Institution. NCI Thesaurus. Code C54140.

A legal entity in the United States which is controlled by the state. Typically a public institution will have a board of trustees who govern the institution and the members of the board are public officials who are appointed by the state (typically a person in the executive branch such as a state governor) for a fixed term of years. 